\title{
Body Mass Index Profile of Physical Education Teacher Candidates
}

\author{
Syafaruddin ${ }^{1}$, Wahyu Indra Bayu ${ }^{2}$, Soleh Solahuddin ${ }^{3}$, Ahmad Richard Victorian ${ }^{4}$ \\ \{ syafaruddin@fkip.unsri.ac.id ${ }^{1}$, wahyu.indra@ fkip.unsri.ac.id ${ }^{2}$, solehsolahuddin@ fkip.unsri.ac.id ${ }^{3}$, \\ richardvictorian@fkip.unsri.ac.id $\left.{ }^{4}\right\}$ \\ Sriwijaya University, Palembang, Indonesia ${ }^{1,2,3,4}$
}

\begin{abstract}
This study aims to analyze the Body Mass Index (BMI) of PE teacher candidates of Sriwijaya University during the Covid-19 pandemic. A survey used as the research method ( $\mathrm{n}=159)$. The data was collected by measuring the height and weight of the candidates, and the BMI was calculated using the formula of body mass divided by the square of the height in $\mathrm{kg} / \mathrm{m} 2$ units. The quantitative data analysis that was used in this study was the percentage of the candidates to map the physical fitness profile based on the BMI. The result of this study shows that the BMI of the candidates were as follows: underweight $28(17,61 \%)$; normal or healthy weight $123(77,36 \%)$, overweight $8(5,03 \%)$. The underweight and overweight candidates are suggested to evaluate and improve their physical activity and nutrition in order to make their physical fitness better and their body weight ideal.
\end{abstract}

Keywords: BMI, PE teacher candidates.

\section{Introduction}

Physical education (PE) is an important part of education holistically, which aims to improve some aspects of students' life through physical activities that are planned systematically to achieve education goals. However, the main aspect which developed through physical activity in physical education is physical fitness, because physical activity encourages students to use their bodies actively and sustainably. Physical activity has been documented to have many benefits among students [1], [2]. The benefit of physical fitness on resilience is in part based on the recognition that physical fitness, achieved through physical activity and/or regular exercise, can induce positive phsychological benefits, protect against the potential consequences or stressfull events, and prevent many chronic disease [3]. Physical fitness is an important indicator of healthy status in children and adolescents, and certainly a good predictor of health status in life [4].

In an educational context, students identify teachers as role models who play an important role in their learning processes [5]. PE teachers require to be fit as the role model of students. A positive role-model that facilitates learning healthy life skills can be developed in a physical education setting [6]. When students see PE teacher in a good shape and practicing healthy lifestyle, they are more likely to want to be fit or practice those healthy behaviors themselves. Ironically, while PE teachers need to fit, previous studies found that some PE teachers deficiencies in physical activity and health-related fitness content knowledge [7], [8]. Without 
sufficient knowledge, it will be more difficult for PE teachers to maintain fitness, let alone teach students practicing healthy lifestyle.

Undergraduate students, whose major is Physical Education, are PE teacher candidates. The students are projected to be PE teachers in the future by studying various aspects related to health science, sports training, sports coaching and other social sciences. While studying, they are also expected to be fit and maintain their physical fitness. The habit of living healthy is one of important factor the undergraduate students must have because they will be the role model of their future students. Although the students are expected to be fit, a previous study shows that more than $20 \%$ undergraduate PE students in overweight or even obesity category [9].

Sriwijaya University is one of state university in Indonesia that has PE major under the Physical Education, Health, and Recreation study program. There are several practical courses (e.g. Basic Basketball Skill, Basic Volleyball Skill, Basic Athletic Skill, etc.) that expected to help maintaining or even improving the undergraduate PE students of Sriwijaya University body mass index (BMI) level. The problem is that during this Covid-19 pandemic there are no practical class and all of classes have been being done online. As schools and universities were ordered to close to contain the spread of the coronavirus, traditional physical classes were transitioned to an online mode of learning. PE centers on physical activity and is clearly distinct from general knowledge-based subjects [10], therefore, online practical learning effectiveness still needs to be tested.

This study aims to analyze the BMI of PE teacher candidates, during the Covid-19 pandemic. The teacher candidates are the undergraduate students of Sriwijaya University Physical Education, Health, and Recreation study program, that still undergoing practical courses using multiple online based learning.

\section{Method}

The research method used in this study was survey method. 159 (97 male and 62 female) undergraduate students of Sriwijaya University Physical Education, Health, and Recreation study program participated in this study through an accidental sampling. The data was collected by measuring the height and weight of the candidates. The measurement was done gradually under covid-19 health protocol. BMI was calculated using the formula of body mass divided by the square of the height in $\mathrm{kg} / \mathrm{m} 2$ units. The quantitative data analysis that was used in this study was the percentage of the candidates to map the physical fitness profile based on the BMI.

\section{Results}

The results which show the overall BMI level of PE teacher candidates in Sriwijaya University Physical Education, Health, and Recreation study program, both male and female can be seen in Table 1 . 
Table 1. Weight and height of teacher candidates

\begin{tabular}{lcccc}
\hline \multirow{2}{*}{ Data } & \multicolumn{2}{c}{ Male } & \multicolumn{2}{c}{ Female } \\
\cline { 2 - 5 } & Mean & St.Dev & 62 & St.Dev \\
\hline $\mathrm{N}$ & 97 & & 19,97 & 0,96 \\
Age & 20,38 & 1,25 & 52,39 & 5,89 \\
Weight $(\mathrm{kg})$ & 60,85 & 8,29 & 158,35 & 5,70 \\
Height $(\mathrm{m})$ & 169,26 & 5,38 & 20,89 & 2,03 \\
BMI $(\mathrm{kg} / \mathrm{m} 2)$ & 21,20 & 2,38 & & \\
\hline
\end{tabular}

Table 1 shows that male PE teacher candidates have a greater body weight, body height and BMI than female candidates. Based on the data in table 1, the physical education teacher candidates in Sriwijaya University Physical Education, Health, and Recreation study program during the Covid-19 pandemic, as folows: The BMI of male PE teacher candidates average is $21,20 \mathrm{~kg} / \mathrm{m} 2$ which is in the normal category, while the status of the average female candidates is $20,89 \mathrm{~kg} / \mathrm{m} 2$ which is also in the normal category (healthy weight).

The detailed profile data of BMI categories for all male and female subjects can be seen in Table 2.

Table 2. BMI category of teacher candidates

\begin{tabular}{|c|c|c|}
\hline Category & Frequency & Precent \\
\hline Underweight & 28 & 17,61 \\
\hline Normal & 123 & 77,36 \\
\hline Overweight & 8 & 5,03 \\
\hline Obese Class I (Moderately Obese) & 0 & 0 \\
\hline Obese Class II (Severely Obese) & 0 & 0 \\
\hline Obese Class III ( Very Severely Obese) & 0 & 0 \\
\hline Total & 159 & 100 \\
\hline
\end{tabular}

Table 2 shows that the BMI of physical education teacher candidates in Sriwijaya University Physical Education, Health, and Recreation study program during the Covid-19 pandemic. There were $123(77,36 \%)$ subject were normal (healthy weight), $28(17,61 \%)$ subject were underweight, and $8(5,03 \%)$ subject were overweight.

\section{Discussion}

PE teacher candidates will certainly become the role models for their students in the future, including in terms of ideal body shape as an example of a healthy lifestyle [11], because one of the task of the PE teachers is teaching about the application and habits of healthy living. Covid19 pandemic is striking all over the world, and this has certainly reduced people's physical activity. If the physical activity decreases, the level of physical fitness also decreases and of course people will have a hard time to control their body weight. In addition, body mass index 
(BMI) is an important factor affecting the level of cardiovascular fitness. Fitness is calculated per unit body weight, thus increasing body fat means decreasing fitness level [12], [13].

The ideal BMI can be obtained by adopting habits of active and healthy living, such as diet planning, balancing nutritional intake, and doing adequate physical activity. A general recommendation for adults to be physically active is to achieve at least 150 minutes of moderateintensity exercise or 75 minutes of vogorous-intensity exercise per week or a combination of both types [14], [15]. Likewise, there is general concern about the negative health implications of physical inactivity and sedentary behavior [16]. Sedentary behavior is defined as any everyday behavior that is practiced while lying down, sitting or standing, which involves energy expenditure $\leq 1.5$ metabolic equivalents [17], [18].

Obesity is recognized as an important risk factor for various diseases. Previous studies shown an increase in all causes of mortality with an increase in BMI, especially the mortality from cardiovascular disease in men [19]. The prevalence of obesity in children and adolesents is increasing along with changes in socio-economic environment and lifestyle patterns [20][22]. Obesity in children is assumed to be related to the risk of obesity and other diseases, such as type II diabetes mellitus or cardiovascular disease. BMI has been considered as an indicator of obesity and is widely used as a screening method for obesity because it is a well-known index for predicting obesity and assessing health risks. High BMI level in childhood will effect the life in adulthood which associate with obesity and high blood pressure [23], [24], and a higher risk of various diseases such as type II diabetes mellitus, stroke, heart attack, atherosclerosis and total mortality $(25,26)$.

The research data shows that from all the participating PE teacher candidates $(n=159)$, the majority $(77.36 \%)$ are in the normal BMI category while the rest are in the underweight $(17.61 \%)$ and overweight $(5.03 \%)$ categories. This could be due to the maintained physical activity of the PE teacher candidates even though they are still in the Covid-19 pandemic condition. Although lectures, both theory and practice, are carried out online, several activities of the PE teacher candidates, who are students of the Physical Education Study Program of Sriwijaya University, are still actively carried out. Student activities such as the Penjas Bicycle Community and the Balbalan Penjas are still active, which are shown in the updated photos on these activities' social media. Even though these activities are actively running, they are not official university activities, so there are no restrictions in implementing them as long as the students still follow the applicable health protocols. These activities are suspected to be the cause of the majority of the PE teacher candidates' normal BMI category. Meanwhile, the PE teacher candidates who are in underweight category are suspected of not meeting nutritional needs or have an ectomorph body type, so it is quite difficult to increase body weight without good nutrition and/or doing weight training, while the PE teacher candidates who are in overweight category are suspected to be less active in participating in activities that are involves physical activity or not maintaining their nutritional balance.

In this study, the level of physical activity and passive activity, or the nutritional intake of the research subjects was not measured, so that the causative factor from the BMI image obtained from this study was unknown. Even so, this research can be used as an initial description to be used as a minimum standard in recruiting students (teacher candidates), especially PE teacher candidates. 


\section{Conclusion}

General description of the BMI of PE teacher candidates, who are currently studying at the Sriwijaya University Physical Education, Health, and Recreation study program, is the absence of the obesity category and a small proportion $(17.61 \%)$ in the underweight category. This must be evaluated individually, both in diet and physical activity, so that the BMI turn into the normal category, and those that have entered the normal category still have to maintain their healthy patterns and habits, so that they are not prone to disease.

\section{References}

[1] Z. D. Bailey, N. Krieger, M. Agénor, J. Graves, N. Linos, and M. T. Bassett. Structural racism and health inequities in the USA: evidence and interventions. The Lancet. 2017. doi: 10.1016/S01406736(17)30569-X.

[2] D. Yang, X. Zhu, J. A. Haegele, P. B. Wilson, and X. Wu. The association between health-related fitness and physical activity during weekdays: Do fit students exercise more after school?. Sustain. 2019. doi: 10.3390/su11154127.

[3] P. A. Deuster and M. N. Silverman. Physical fitness: a pathway to health and resilience. U.S. Army Medical Department journal. 2013.

[4] D. Cvejić, T. Pejović, and S. Ostojić. Assessment of physical fitness in children and adolescents. Facta Univ. - Ser. Phys. Educ. Sport. 2013; 11 (2): 135-145.

[5] P. Cheung. Teachers as role models for physical activity: Are preschool children more active when their teachers are active?. Eur. Phys. Educ. Rev. 2020. doi: 10.1177/1356336X19835240.

[6] B. Filiz and F. Konukman. Teaching Strategies for Physical Education during the COVID-19 Pandemic: Editor: Ferman Konukman. Journal of Physical Education, Recreation and Dance. Routledge. 2020; 91(9): 48-50. doi: 10.1080/07303084.2020.1816099.

[7] D. Castelli and L. Williams. Health-related fitness and physical education teachers' content knowledge. J. Teach. Phys. Educ. 2007. doi: 10.1123/jtpe.26.1.3.

[8] J. A. Santiago, J. G. Disch, and J. Morales. Elementary physical education teachers' content knowledge of physical activity and health-related fitness. Phys. Educ., 2012.

[9] A. Haqiyah, M. Muhamad, B. Bujang, A. Mylsidayu, and E. D. Mamesah. Body Mass Index and Physical Fitness Profile of Physical Education Students. 2020. doi: 10.2991/ahsr.k.200214.103.

[10] H.-C. Jeong and W.-Y. So. Difficulties of Online Physical Education Classes in Middle and High School and an Efficient Operation Plan to Address Them. Int. J. Environ. Res. Public Health. 2020; 17(19): 7279. doi: 10.3390/ijerph17197279.

[11] C. A. Huber, M. Mohler-Kuo, U. Zellweger, M. Zoller, T. Rosemann, and O. Senn. Obesity management and continuing medical education in primary care: Results of a Swiss survey. BMC Fam. Pract. 2011; 12 (1): 146. doi: 10.1186/1471-2296-12-140.

[12] K. D. P. Andrastea, I. N. M. Karmaya, and I. N. G. Wardana. Hubungan indeks massa tubuh dengan tingkat kebugaran kardiovaskular pada mahasiswi Program Studi Pendidikan Dokter, Fakultas Kedokteran Universitas Udayana usia 18-21 tahun. Bali Anat. J. 2018; 1(2): 30-34. doi: https://doi.org/10.36675/baj.v1i2.16.

[13] Widiyanto. Metode pengaturan berat badan. Med. J. Ilm. Kesehat. Olahraga. 2015; 1 (2): 105-118. doi: $10.21831 /$ medikora.v1i2.4772.

[14] WHO. Global recommendations on physical activity for health. 2010.

[15] WHO. Physical activity. 2020.

[16] G. Hall, D. R. Laddu, S. A. Phillips, C. J. Lavie, and R. Arena. A tale of two pandemics: How will COVID-19 and global trends in physical inactivity and sedentary behavior affect one another?. Prog. Cardiovasc. Dis. 2020; 64: 108-110. doi: 10.1016/j.pcad.2020.04.005.

[17] M. S. Tremblay et al. Sedentary Behavior Research Network (SBRN) - Terminology consensus project process and outcome. Int. J. Behav. Nutr. Phys. Act. 2017; 14 (1): 75. doi: 10.1186/s12966017-0525-8. 
[18] M. Mansoubi et al. Energy expenditure during common sitting and standing tasks: Examining the 1.5 MET definition of sedentary behaviour. BMC Public Health. 2015; 15(1): 516. doi: 10.1186/s12889-015-1851-x.

[19] E. E. Calle, M. J. Thun, J. M. Petrelli, C. Rodriguez, and C. W. Heath. Body-Mass Index and Mortality in a Prospective Cohort of U.S. Adults. N. Engl. J. Med. 1999; 341 (15): 1097-1105. doi: 10.1056/nejm199910073411501.

[20] J. C. Han, D. A. Lawlor, and S. Y. Kimm. Childhood obesity. Lancet. 2010; 375 (9727): 1737-1748. doi: 10.1016/S0140-6736(10)60171-7.

[21] S. E. Barlow. Expert committee recommendations regarding the prevention, assessment, and treatment of child and adolescent overweight and obesity: summary report. Pediatrics. 2007; 120 (Suppl 4). doi: 10.1542/peds.2007-2329C.

[22] C. L. Ogden, M. D. Carroll, B. K. Kit, and K. M. Flegal. Prevalence of obesity and trends in body mass index among US children and adolescents, 1999-2010. JAMA - J. Am. Med. Assoc. 2012; 307 (5): 483-490. doi: 10.1001/jama.2012.40.

[23] D. S. Freedman, L. K. Khan, M. K. Serdula, W. H. Dietz, S. R. Srinivasan, and G. S. Berenson. The relation of childhood BMI to adult adiposity: The Bogalusa heart study. Pediatrics. 2005; 115 (1): 22-27. doi: 10.1542/peds.2004-0220.

[24] E. W. Gregg et al. Secular trends in cardiovascular desease risk factors according to body mass index in US adults. J. Am. Med. Assoc. 2005; 293 (15): 1868-1874. doi: 10.1001/jama.293.15.1868.

[25] T. Bjørge, A. Engeland, A. Tverdal, and G. D. Smith. Body mass index in adolescence in relation to cause-specific mortality: A follow-up of 230,000 Norwegian adolescents. Am. J. Epidemiol. 2008; 168 (1): 30-37. doi: 10.1093/aje/kwn096.

[26] Y. Wang et al. Relationship between body adiposity measures and risk of primary knee and hip replacement for osteoarthritis: A prospective cohort study. Arthritis Res. Ther. 2009; 11 (2) Mar. doi: $10.1186 / \operatorname{ar} 2636$ 